\title{
How useful is HPV-DNA test for screening of cervical cancer: a prospective study
}

\author{
Vineeta Gupta*, Archana Tandon, Neeta Bansal, Anuja Nanda
}

\begin{abstract}
Department of Obstetrics \& Gynaecology, Shri Guru Ram Rai, Institute of Medical \& Health Sciences, Shri Mahant Indiresh Hospital, Dehradun 248001, India
\end{abstract}

Received: 22 December 2015

Accepted: 16 January 2016

\author{
*Correspondence: \\ Dr. Vineeta Gupta, \\ E-mail: vineetahims@yahoo.co.in
}

Copyright: (c) the author(s), publisher and licensee Medip Academy. This is an open-access article distributed under the terms of the Creative Commons Attribution Non-Commercial License, which permits unrestricted non-commercial use, distribution, and reproduction in any medium, provided the original work is properly cited.

\begin{abstract}
Background: The aim of present study was to evaluate the utility of HPV-DNA testing in cervical cancer screening. Methods: The study included 110 women presenting to the Gynaecological OPD of SMI Hospital who were subjected to HPV DNA test and one or more of other tests like cytology, colposcopy and histopathological examination. The results were evaluated by standard statistical methods.

Results: Out of 110 patients in whom HPV-DNA testing was done, 24 had positive result, 83 had negative result and 3 had borderline test result. Sensitivity \& Specificity of HPV-DNA testing was calculated to be $90 \%$ and $84.61 \%$ respectively. Its positive predictive value and negative predictive value were $69.23 \%$ and $95.66 \%$. The percentage of false negative was calculated to be $10 \%$ and that of false positive was $15.38 \%$.

Conclusions: In our study, the sensitivity and negative predictive value of HPV-DNA testing was found to be more as compared to its specificity and positive predictive value. Widespread HPV testing for primary cervical cancer screening is not recommended as it will increase the volume of HPV testing and will not be cost- effective. It may be used for secondary screening in patients with abnormal or (ASC) cytology results as this will help in their subsequent management.
\end{abstract}

Keywords: HPV-DNA test, Cervical cancer screening

\section{INTRODUCTION}

Cancer of the cervix continues to be the most common genital tract cancer seen in females in India. Primary cervical cancer screening by cytological examination of cervical cells with PAP smear has reduced the incidence of cervical cancer in countries with organized screening programmes. In the past decade, the International Agency of Research on Cancer (IARC) observed that an appropriate test is needed for low-resource settings and recommended that any such test should be carefully evaluated in demonstration projects. ${ }^{1}$ Given the evidence concerning the etiologic role of oncogenic HPV infection in development of cervical cancer and CIN, HPV testing has been proposed as a method to identify women at increased risk of cervical cancer. The present study was, therefore, undertaken to evaluate the role of HPV-DNA testing in cervical cancer screening.

\section{METHODS}

In the present study, we included patients from the Gynaecological OPD of our hospital. Women with, lower abdominal pain, low backache, intermenstrual bleeding, postcoital bleeding, persistent vaginal discharge, vulval itching or burning, persistent dysuria, menstrual irregularities, cervical erosion, unhealthy cervix or other complaints were included in the study. 
Clinical examination was done in all the patients. Most of these patients had already had done other tests like cytology and/or colposcopy. After informed consent, these patients were subjected to HPV DNA test. HPVDNA was done by Digene hybrid capture system. It was a non PCR test and based upon linear signal amplification of the target DNA. The test was negative if the values were less than 0.80 , borderline if the values were between 0.81 to 1.20 and positive if more than 1.20 . The results were evaluated by standard statistical methods. Histopathological examination was taken as the goldstandard test to calculate the sensitivity, specificity, positive and negative predictive value of HPV-DNA test.

\section{RESULTS}

Hundred and ten patients were included in the study in whom HPV-DNA test was done. Out of these, 83 had negative result, 24 had positive result and 3 had borderline test result. As seen in Table 1, on the basis of clinical and cytological findings, out of 24 patients with positive HPV-DNA result, 4 had chronic cervicitis, 1 had LGSIL, 18 had invasive squamous cell carcinoma \& 1 patient had vaginal warts. Out of 83 patients with negative HPV- DNA, 71 had chronic cervicitis, 9 had LGSIL, 2 had HGSIL \& 1 had genital warts. Out of 3 patients with borderline HPV-DNA, 2 had chronic cervicitis \& 1 had LGSIL.

Table 1: Results of HPV- DNA testing (110 patients).

\begin{tabular}{|llll|}
\hline & $\begin{array}{l}\text { Positive } \\
(24)\end{array}$ & $\begin{array}{l}\text { Negative } \\
(83)\end{array}$ & $\begin{array}{l}\text { Borderline } \\
(3)\end{array}$ \\
\hline $\begin{array}{l}\text { Chronic } \\
\text { cervicitis }\end{array}$ & 4 & 71 & 2 \\
\hline LGSIL & 1 & 9 & 1 \\
\hline $\begin{array}{l}\text { HGSIL/ } \\
\text { Ca Cervix }\end{array}$ & 18 & 2 & 0 \\
\hline Warts & 1 & 1 & 0 \\
\hline
\end{tabular}

Cervical biopsy and histopathological examination was done in 72 patients. Thirty-eight patients with negative HPV-DNA test report refused for cervical biopsy and histopathological examination. Correlation between HPV-DNA \& HPE has been shown in Table 2. It was seen that there was correlation between HPV-DNA and HPE in $85.36 \%$ patients with chronic cervicitis and $90 \%$ patients with HGSIL and Invasive Cervical cancer. In patients with LGSIL, HPV DNA was found to be positive only in $18.18 \%$ patients while it was negative in $81.82 \%$ patients. Sensitivity \& Specificity of HPV-DNA testing was calculated to be $90 \%$ and $84.61 \%$ respectively. Its positive predictive value and negative predictive value were $69.23 \%$ and $95.66 \%$. The percentage of false negative was calculated to be $10 \%$ and that of false positive was $15.38 \%$.
Table 2: Correlation between HPE \& HPV-DNA (72 patients).

\begin{tabular}{|lll|}
\hline HPE & HPV-DNA & \\
\hline $\begin{array}{l}\text { Chronic } \\
\text { cervicitis (41) }\end{array}$ & $6(14.63)$ & Negative \\
\hline LGSIL (11) & $2(18.18 \%)$ & $35(85.36)$ \\
\hline $\begin{array}{l}\text { HGSIL/Invasive } \\
\text { Ca Cx }(20)\end{array}$ & $18(90 \%)$ & $9(81.82 \%)$ \\
\hline
\end{tabular}

* both patients had CIN -2

\section{DISCUSSION}

The role of HPV-DNA testing in cervical cancer screening is insufficiently documented. Various authors have given different opinions regarding the usefulness of HPV-DNA testing in many studies conducted all over the world. Pontus Naucler et al reported that compared with screening by cytology alone, double testing with cytology and for type-specific HPV persistence resulted in $35 \%$ increase in sensitivity to detect $\mathrm{CIN} 3+$, without a statistically significant reduction in the PPV, but with more than twice as many screening tests needed. ${ }^{2}$ The authors concluded that primary HPV-DNA based screening with cytology triage and repeat HPV DNA testing of cytology-negative women appears to be the most feasible cervical screening strategy.

Pajtler et al found that in comparison with repeat cytology, HPV DNA test showed higher sensitivity $(69.2 \%$ vs $61.5 \%)$ but significantly lower specificity $(63.2 \%$ vs $93.0 \%)$ and positive predictive value $(30.0 \%$ vs $66.7 \%$ ) and comparable negative predictive value $(90.0 \%$ vs $91.4 \%)$ in predicting histologically verified CIN3. The authors concluded that HPV testing is of limited value in daily routine and should not be widely used until it is definitely demonstrated to be superior to conventional methods in improving the sensitivity, specificity and predictive value of CIN3 and invasive carcinoma detection. ${ }^{3}$

Schiffman M et al found in their study that PAP testing using ASCUS as a cut off point for referral resulted in $77 \%$ sensitivity and $94.2 \%$ specificity with $6.9 \%$ referral $^{4}$. The sensitivity and specificity of the HPV testing with the original assay of higher detection threshold of $10 \mathrm{pg} / \mathrm{ml}$ was $74.8 \%$ and $93.4 \%$ respectively. Lower levels of detection with the second generation assay $(1 \mathrm{pg} / \mathrm{ml})$ proved clinically nonspecific without gains in diagnostic sensitivity. The authors concluded that because HPV prevalence varies by population, positive predictive value of HPV testing for detection of high grade lesions and cancer will vary accordingly, with implications for utility relative to other cervical cancer screening methods.

In the ASCUS/LSIL triage study (ALTS trial), $80 \%$ of the women who had a cytologic diagnosis of LSIL were found to harbour HPV DNA. ${ }^{7}$ The study concluded that 
HPV testing was not of value in the management of women found to have LSIL on cytological examination. ${ }^{5}$ In the same trial in women with ASC-US it was found that HPV testing detected $96.30 \%$ of women with previously undiagnosed CIN 3 or cancer \& resulted in the referral of only $56.1 \%$ of women for colposcopy.

In a study on Icelandic population, 358 cases with abnormal smears who were referred for colposcopy and HPV DNA testing were included. ${ }^{6}$ The authors concluded that high risk HPV and high grade smears are complimentary for the diagnosis of high grade histologic lesions and the present role of HPV testing in screening could be limited to identifying women with low-grade smears and koilocytic or low-grade colposcopic biopsies that are at risk of concealing or developing high grade histologic lesions.

In a study by M. Michele Manos et al, 995 women were evaluated using HPV DNA testing for equivocal Pap results $^{7}$. The objective of their study was to determine whether HPV DNA testing of residual material from liquid-based Pap tests and referral of cases found to be HPV positive directly to colposcopy could provide sensitive detection of underlying HSILs in women with ASCUS Pap results, compared with repeat Pap testing. The sensitivity of HPV DNA testing for HSIL was equivalent to that of the repeat PAP test. The authors estimated that an HPV- based algorithm including the immediate colposcopy of HPV-positive women, and then repeat PAP testing of all others, would provide an overall sensitivity of $96.9 \%$. In our study, in patients with LGSIL cytology results, HPV-DNA was negative in $81.82 \%$ patients and therefore, referral of such cases for colposcopy may be deferred. On the other hand, patients will HGSIL cytology results can be directly referred for colposcopy and guided cervical biopsy, if required. This will save time and resources as in these patients, majority will have HPV-DNA test result positive \& ultimately require colposcopy as was seen in our study. It may be used for secondary screening in patients with abnormal or (ASC) cytology results as this will help in their subsequent management.

Comparison of sensitivity and specificity of HPV-DNA testing between various studies with our study has been shown in Table 3.

Table 3: Comparison between various studies.

\begin{tabular}{|lllll|}
\hline HPV & Pajtler & Manos & $\begin{array}{l}\text { Schiffman } \\
\text { DNA }\end{array}$ & $\begin{array}{l}\text { Present } \\
\text { study }\end{array}$ \\
\hline Sensitivity & $69.2 \%$ & $89.2 \%$ & $74.8 \%$ & $90 \%$ \\
\hline Specificity & $63.2 \%$ & $64.1 \%$ & $93.4 \%$ & $84.61 \%$ \\
\hline
\end{tabular}

One of the drawbacks of universal HPV-DNA primary screening is that a large number of women with transient high risk HPV infection have normal cytology findings and no disease. Another limitation of HPV DNA testing is that its specificity is lower in younger patients. Age- specific evaluation of primary HPV screening versus conventional cytology was carried out in a randomized setting in Finland. ${ }^{8}$ The specificity of the HPV DNA test with cytology triage was equal to that of conventional screening for all age groups $(99.2 \%$ vs $99.1 \%$ for CIN $2+)$. Among women aged 35 years or older, the HPV DNA test with cytology triage tended to have higher specificity than conventional screening. The PPVs for HPV DNA screening with cytology triage were consistently higher than those for conventional screening. In both screening arms, the test specificities increased with increasing age of the women being screened, whereas the highest PPVs were observed among the youngest women being screened. The authors concluded that primary HPV DNA screening with cytology triage is more sensitive than conventional screening. Among women aged 35 years or older, primary HPV DNA test with cytology triage is also more specific than conventional screening and decreases colposcopy referrals and follow-up tests.

Kulasingam et al reported that HPV DNA test was found to have higher sensitivity but lower specificity for detecting high grade lesions. ${ }^{9}$ Moreover, HPV test was more sensitive for identifying CIN3 or higher lesions in women younger than 30 years of age. Test specificity was significantly greater for women older than 30 years of age. In our study out of 6 patients with chronic cervicitis with positive HPV DNA, 4 patients were less than 35 years age. Therefore, specificity of HPV-DNA testing is lower in young patients. In some studies, up to $70 \%$ of college-going women were found to be HPV-DNA positive that is usually transient and infection cleared in $90 \%$ of women. ${ }^{10,11}$ Therefore, HPV screening should be initiated only after 30 years in order to exclude transient positive cases ${ }^{12}$. Sherman et al reported that HPV testing in women older than 30 years has an average sensitivity and specificity of 89 and $90 \%$ with negative predictive value greater than $97 \% .^{13}$

In counselling women, it is important to remember that it is the persistence of high risk HPV-DNA type that is a high risk factor for cervical carcinoma. The downside to universal HPV-DNA primary screening is that a large number of women with transient high risk HPV infection have normal cytology findings and no disease. This leads to unnecessary treatment and anxiety.

\section{CONCLUSIONS}

In our study, the sensitivity and negative predictive value of HPV-DNA testing was found to be more as compared to its specificity and positive predictive value. Widespread HPV testing for primary cervical cancer screening is not recommended as it will increase the volume of HPV testing and will not be cost-effective. It may be used for secondary screening in patients with abnormal or (ASC) cytology results as this will help in their subsequent management. In future, in combination with liquid-based cytology, HPV-DNA testing may 
become more convenient and cost-effective. It is also important that HPV testing as a screening method should not be used in young women because of the high false positive rates, which leads to unnecessary treatment and psychological burden on both the patient and the doctor.

Funding: No funding sources

Conflict of interest: None declared

Ethical approval: The study was approved by the Institutional Ethics Committee

\section{REFERENCES}

1. IARC Handbooks of cancer prevention. Vol 10. Cervix cancer screening. IARC press, Lyon. 2005.

2. Naucler P, Ryd W, Tornberg S, Strand A, Wadell G, Elfgren K, et al. Efficacy of HPV Testing with cytology Triage and/or Repeat HPV DNA Testing in Primary cervical cancer Screening. JNCI Journal of the National Cancer Institute. 2009;101(2):88-99.

3. Pajtler M, Milicic-Juhas V, Milojkovic M, Topolovec Z, Curzik D, Mihaljevic I. Assessment of HPV DNA test value in management of women with cytological findings of ASC-US, CIN 1 and CIN 2. Coll Antropol. 2010;34(1):81-6.

4. Schiffman M, Herrero R, Hildesheim A, Sherman ME, Bratti M, Wacholder S. HPV DNA testing in cervical cancer screening: results from women in a high risk province of Costa-Rica. JAMA. 2000;283(1):87-93.

5. The atypical squamous cells of undetermined significance/low-grade squamous intraepithelial lesions triage study (ALTS) Group. Human papillomavirus testing for triage of women with cytologic evidence of low-grade squamous intraepithelial lesions: baseline data from a randomized trial. I Natl Cancer Inst. 2000;92:397402.

6. Sigurdsson K, Amadottir T, Snorrad M, Benediktsdottir K, Saemundsson H. Human papillomavirus (HPV) in an Icelandic population: The role of HPV DNA testing based on hybrid capture and PCR assays among women with screen detected abnormal pap smears. Int $\mathrm{J}$ Cancer. 1997:72:446-52.

7. Manos MM, Kinney WK, Hurley LB, Sherman ME, Jen Shies-Negi, Kurman RJ, et al. Identifying women with Cervical Neoplasia. JAMA. 1999;281:1605-10.

8. Leinonen M, Nieminen P, Kotaniemi- Talonen L, Malila N, Tarkkanen J, Laurila P. Age-Specific Evaluation of Primary Human Papillomavirus Screening vs Conventional Cytology in a Randomized Setting. J Natl Cancer Inst. 2009;101:1612-23.

9. Kulasingam SL, Hughes JP, Kiviat NB. Evaluation of human papillomavirus tasting in primary screening for cervical abnormalities. JAMA. 2002;288:1749-57.

10. Ho GY, Bierman R, Beardsley L, Chang CJ, Burk RD. Natural history of cervicovaginal papillomavirus infection in young women. $\mathrm{N}$ Engl $\mathrm{J}$ Med. 1998;338:423-8.

11. Wheeler CM, Greer CE, Becker TM, Hunt WC. Anderson SM, Manos MM. Short-term fluctutions in the detection of cervical human papillomavirus DNA. Obstet Gynecol. 1996

12. Bhatla N, Moda N. The clinical utility of HPV-DNA testing in cervical cancer screening strategies. Indian J Med Res. 2009;130:261-5.

13. Sherman ME, Lorincz AT, Scott DR, Wacholder S, Castle PE, Glass AG. Baseline cyrology human papillomavirus testing and risk for cervical neoplasia: a 10-year cohort analysis. J Natl Cancer Inst. 2003;95:46-52.

Cite this article as: Gupta V, Tandon A, Bansal N, Nanda A. How useful is HPV-DNA test for screening of cervical cancer: a prospective study. Int J Reprod Contracept Obstet Gynecol 2016;5:456-9. 